\title{
Editor's message: Current state of hydrogeology education in Iran and the major shortfalls
}

\author{
Gholam A. Kazemi
}

Keywords Iran · Education

The classical education of 'Hydrogeology' in Iran does not trace back to long ago, despite the notion that the invention of the qanat, the oldest yet scientifically and ecologically sound groundwater abstraction system, is credited to Ancient Persia and despite the fact that Iran depends on groundwater for more than $50 \%$ of its water needs. Currently, there are seven governmental universities and one private university that offer MSc programs in hydrogeology; three of these offer courses leading to $\mathrm{PhD}$ degrees. Shiraz University, the first institution to provide a hydrogeology course in Iran, commenced its Masters program only 20 years ago in 1988 . A PhD program in hydrogeology was founded by the same university, but 10 years later in 1998. However, before the 1979 Iranian Revolution, there were scattered institutions which used to run MSc programs in hydrogeology but not on a sizeable routine basis.

Institutions currently involved in hydrogeology education include, in the order of starting date of the program, Shiraz University (Shiraz), Shahid Chamran University (Ahvaz), Shahid Beheshti University (Tehran), University of Tabriz (Tabriz), University of Sistan and Baluchestan (Zahedan), Shahrood University of Technology (Shahrood) and Tarbiat Moalem University in Tehran. The private university, namely Islamic Azad University offers an MSc in hydrogeology at its Tehran branch of Science and Research. Out of these, Shiraz, Shahid Beheshti and very recently Tabriz University offer $\mathrm{PhD}$ programs. Depending on the human capacity and facilities available,

Received: 13 December 2008 / Accepted: 2 March 2009

Published online: 20 March 2009

C) Springer-Verlag 2009

G. A. Kazemi ( $)$

Faculty of Earth Sciences,

Shahrood University of Technology,

University Boulevard, Shahrood, 3619995161, Iran

e-mail: g a kazemi@shahroodut.ac.ir

Tel.: +98-273-3336007

Fax: +98-273-3334419 every year or every two years, these universities admit up to three $\mathrm{PhD}$ students each. Annual intake of MSc students is limited to fewer than 10 for each university. The spatial distribution of these institutions in the north, south, east and west of the country is uniform, enabling universities to cover all parts of the country in terms of hydrogeology research and education. It is estimated that some 500 hydrogeologists with MSc degrees and about 10 hydrogeologists with $\mathrm{PhD}$ degrees have graduated from all the above intuitions during the last two decades. It has to be pointed out that the above data are pertinent to hydrogeologists, i.e. graduates with background in geology who completed their studies at geology, geosciences or earth sciences departments. MSc programs in groundwater in civil engineering, irrigation engineering or water engineering departments are treated differently and are not discussed here. Subjects taught at these departments often are similar to hydrogeology subjects; a good discussion in this regard is the paper by Weissmann (2006).

Geology is a less important subject in high school in Iran. It is taught for only two hours per week, and during the last two years only, to students who choose the experimental sciences field (There are four fields of study in high school: experimental sciences, mathematics and physics, humanities, and arts.) In addition, the quality of performance in the subject of geology has little impact for high school graduates who decide to continue their studies towards higher education in universities. Moreover, because of the physical harshness of this field of study, for a period of time there was a ban on girls entering undergraduate geology courses, although the ban has now been lifted. One more disappointing fact is that at the universities, the curriculum of undergraduate studies in geology involves only two subjects of hydrogeology and hydrogeochemistry, with the latter even being an elective subject. Despite this dire picture of geology, the situation for hydrogeology in graduate and postgraduate programs is bright. Among all sub-disciplines of geology, namely sedimentlogy and sedimentary rocks, paleontology and stratigraphy, environmental geology, petroleum geology, tectonics and structural geology, economic geology, petrology, engineering geology, hydrogeology, and geophysics, the last three are the most preferred ones by 
geology students that decide to pursue graduate and postgraduate studies. This is mainly due to a better job market and the nature of these disciplines. These fields incline toward physics, chemistry and mathematics, while the other fields of geology require a good memory. One would expect to see petroleum geology as the main favorite among geology graduates in Iran. However, this is not the case mainly due to the very limited number (1-3) of universities that offer this course so the chance of admission is very low and also due to the fact that petroleum companies employ a range of graduates which often can equally carry the duties of petroleum geologists. These include paleontologists, sedimentologists, structural geologists and geochemists.

It takes about 2.5-3 years to complete the hydrogeology program in universities in Iran, with minimum of 2 and maximum of 3 years. This duration is usually equally divided between coursework and research. Compulsory subjects included in the curricula of hydrogeology programs consist of advanced hydrogeology, advanced hydrology, tracers, groundwater abstraction, groundwater modeling, and groundwater hydraulics. In addition to the compulsory subjects, the students must at least enroll for four elective subjects. The elective subjects are widely ranging and include, among others, artificial recharge and subsurface dams, groundwater in geotechnical issues, karst geomorphology, applied hydrology, fundamental of hydraulics and Quaternary geology. With the exception of advanced hydrogeology and groundwater hydraulics, which are four hours per week duration throughout the semester, all the other elective and compulsory subjects are two hours per week in duration. More than $80 \%$ of the above subjects are officially designated as 'theory', with only a couple of them having a laboratory section. However, field trips and excursions are an integral part of most of them, unofficially. In terms of research topics, out of $94 \mathrm{MSc}$ theses written at Shiraz University during the last 20 years, $60 \%$ dealt with karst hydrogeology, $20 \%$ hydrogeochemistry, 10\% general hydrogeology, $7 \%$ modeling, and 3\% surface hydrology (E. Raeisi, Shiraz University, personal communication, December 2008). Interest in karst hydrogeology at Shiraz University is mainly due to the closeness of extensive karstified and carbonate aquifers and high discharge karstic springs. At the other universities, less weight is given to karst hydrogeology, while hydrogeochemistry, environmental and groundwater quality issues are more on the agenda.

In addition to presenting the above statistics, this article points to two deficiencies in the current state of education in hydrogeology in Iran that have affected the quality of research and teaching in this field. These are the lack of laboratory facilities for isotope analysis and the lack of effective international collaboration. Of course some other shortfalls exist but these are the serious ones. At the onset of this article, it was pointed out that Iran, with an annual average rainfall of circa $250 \mathrm{~mm}$, relies heavily on groundwater resources. Furthermore, in some regions, and indeed in a large part of the country, groundwater is the sole source of water for domestic, agricultural and industrial purposes. So, one can easily appreciate the vital importance and the role of groundwater resources for the well being and sustainable development of the country. Therefore, all capacities should be employed, all expertise should be explored, and all avenues must be searched to optimally manage such resources especially as we enter the twenty-first century, the century during which 'wars will be fought over water' (Serageldin 1995)

For proper management of any groundwater resource, information, data and skills are required. To acquire the most effective and the most useful data concerning one region's groundwater resources, laboratory facilities and up to date field sampling equipment are needed. Unfortunately, isotope hydrology and isotope hydrogeology data, which are the most accurate and the most effective piece of scientific evidence, are virtually totally absent from hydrogeological research in Iran. In universities and research institutions, there are no mass spectrometers with the minimum capability to measure any of the common, now routine, environmental tracers such as ${ }^{2} \mathrm{H},{ }^{18} \mathrm{O},{ }^{15} \mathrm{~N}$, ${ }^{13} \mathrm{C},{ }^{14} \mathrm{C}$ and ${ }^{3} \mathrm{H}$; let alone more advanced spectrometers which can measure strontium, chloride or iodine tracers. For any single one of these isotopes, water samples must be sent to foreign laboratories which require extensive administration, time and money, and yet the results are of less precision due to the time elapsed since sampling and due to the storage requirements of the samples, which are often not fully met. The teaching curricula of both MSc and $\mathrm{PhD}$ programs include one tracer subject which comprises environmental as well as applied tracers. How can a university professor teach such subjects with reasonable quality while he/she has no access to a mass spectrometer? Is there not a necessity to demonstrate these instruments to students? To numerate this argument, one has to look at the content of the papers presented at the last four national/regional Iranian conferences on water resources and groundwater. Out of 988 papers presented at these forums, there is only one article that involves isotope measurements, while $40 \%$ of these papers deal with hydrogeochemistry, groundwater quality and groundwater contamination, which clearly points to the weight of chemical hydrogeology in groundwater research in Iran. The situation with regard to MSc theses is the same. Very rarely does an MSc thesis include some measurement of isotopes. To finalize this argument, the author points to his experience in June 2008, in carrying water samples for isotopic analysis to Hokkaido University, Japan. This involved, among other troubles, complicated Customs declaration procedures, limitation in taking samples into the aircraft and lengthy analysis time. At the end of this argument, the author appreciates the disappointing reality that isotope analyses are not routine worldwide anyway. However, the difference with Iran is that groundwater may not be as equally important for countries with similar shortfalls. Furthermore, these countries may be able to access the facilities of their neighboring countries easier. 
International collaborative research is needed to exchange ideas, to learn from others and to import and transfer both technology and expertise. These are required to manage any natural resource optimally. Due to political and some other restrictions, such types of collaborative research between Iranian and foreign scientists are minimal. The author has not come across any systematic sustained inter-country hydrogeology research in Iran. As an example, and to appreciate the consequences of such a situation, one has to look at the number of Iranians who are a member of the International Association of Hydrogeologists (IAH) and compare it with neighboring Turkey whose population is the same, yet posses more surface water. As of December 2008, membership amounts to 7 for Iran and 19 for Turkey. Russia has the same number of IAH members as Turkey. The other neighboring countries of Iraq, Afghanistan and Pakistan have low numbers of IAH members, similar to Iran, but Turkey is the right country to compare. One other example is that the 5th World Water Forum will be held in March 2009 in Turkey, but such a huge event or similar ones are unlikely to be held in Iran. At present, the topics that need international expertise include, among others, aquifer storage and recovery (ASR), bioremediation and other forms of remediation of contaminated aquifers, recharge estimation techniques using isotopes, submarine groundwaters and submarine springs, and waste disposal and its impacts on groundwater resources, and hydrogeochemical models.

Note that Professor Ezzat Raeisi from Shiraz University is an icon among the Iranian hydrogeologists. He is the founder of both MSc and $\mathrm{PhD}$ programs in this field and is respected by all hydrogeologists, whether in universities, in governmental departments or in private companies. Virtually all current Iranian hydrogeologists, with the exception of few who completed their higher education in foreign countries, have been Prof. Raeisi's student at one time or another.

Acknowledgements The review and comments by HJ Managing Editor, Prof. Schafmeister and editorial revisions by Ms. Duncan of the IAH have helped to improve this article considerably.

\section{References}

Serageldin I (1995) If the wars of this century were fought over oil, the wars of the next century will be fought over water. Interview with Newsweek, August 1995 Issue

Weissmann GS (2006) Hydrogeology: teaching groundwater hydrology outside the engineering box. Geol Soc Am Abstr Progr 38(7):428 